\title{
PENGOLAHAN AIR GAMBUT MENJADI AIR BERSIH SECARA KONTINYU DI DESA PEUNAGA CUT UJONG
}

\author{
Kiswanto $^{1^{*}}$, Wintah ${ }^{2}$, Nur laila Rahayu ${ }^{3}$, Endah Sulistiyowati ${ }^{4}$ \\ ${ }^{1}$ Fakultas Teknik Industri Universitas Teuku Umar Meulaboh \\ ${ }^{2}$ Fakultas Kesehatan Universitas Teuku Umar Meulaboh \\ ${ }^{3,4}$ Fakultas Sains dan Teknologi Universitas Nahdhotul Ulama
}

Korespondensi: kiswantoanto5@gmail.com, syuga_2006@yahoo.co.id

\begin{abstract}
Peat water has a brown color, humic acid content, organic substances, iron and $\mathrm{pH}$ levels are very high. To overcome the problem of peat water to be made clean water need to be processing first. Continuous processing of peat water includes; Neutralization, aeration, coagulation - flokulation, and filtration is a complete set of processes but is packaged in a simple form. This process is designed according to the condition and level of education of rural communities in peat water treatment. This study was conducted at a shelter in the village of Peunaga Cut Ujong Meurebo West Aceh. This research aims to reduce acidity, color, turbidity, flavor, iron ( $\mathrm{Fe})$, Zeng ( $\mathrm{Zn})$, organic matter, nitrate $\left(\mathrm{NO}_{3}\right)$, and Nitrit $\left(\mathrm{NO}_{2}\right)$. The research method is an experimental that is directly applied in the field. From the laboratory results in the UPTD Health Banda Aceh has been conducted test water quality before and after processing there are significant results. The results of experimental studies through the simple design of continuous processing using natural materials such as gravel, sand, charcoal and palm fiber and the chemical filling of the capor and alum obtained the results of color dissipation achieved $93.3 \%$, pH of $98.3 \%$, turbidity/cloudiness reached $91.9 \%$, organic substance $\left(\mathrm{KMNO}_{4}\right)$ of $73.3 \%$, hardness of $39.7 \%$, iron $(\mathrm{Fe}) 94.6 \%$, zinc $(\mathrm{Zn})$ of $91.09 \%$, Flurode $77.33 \%$, Nitrate $\left(\mathrm{NO}_{3}\right)$ of 80.04\%, and Nitrit $\left(\mathrm{NO}_{2}\right)$ 99.31\%. Meanwhile, the result of peat water is no smell and feel. The results of this trial are still under the standard quality of Permenkes RI No. 416/Menkes/PER/IX/1990 on the water quality requirements.
\end{abstract}

Keywords: Peat, Continuous, Coagulan, Neutralization

\section{PENDAHULUAN}

Aceh Barat merupakan wilayah yang memiliki topografi tanah gambut. Masyarakat di Aceh Barat memiliki permasalahan tentang bagaimana mendapatkan air bersih sementara air yang banyak disekitar mereka adalah air gambut. Zat organik pada air gambut didominasi oleh senyawa humat yang bersifat sulit dirombak oleh mikroorganisme atau bersifat nonbiodegradable (Zouboulis, 2004).

Untuk wilayah yang mempunyai lahan gambut semakin sulit untuk mendapatkan air bersih. Biasanya lahan gambut lebih didominasi oleh air gambut yang mempunyai ciriciri pH asam, intensitas warna dan bahan organik yang sangat tinggi(Suherman, 2013).

Menurut Kusnaedi, (2006) Pengolahan air masa tanggap darurat fase emergency yakni; menurunkan kekeruhan, mengurangi bau, rasa, warna, menurunkan dan mematikan mikroorganisme serta mengurangi kadar bahan-bahan yang terlarut dalam air, menurunkan kesadahan, memperbaiki derajad keasaman. Secara kualitas, persyaratan untuk air bersih harus memenuhi syarat kesehatan yang ditinjau dari segi fisika, kimia dan biologi. Standar kualitas baku mutu air bersih atau air untuk kebutuhan rumah tangga ditetapkan berdasarkan Peraturan Menteri Kesehatan RI No. 416/Men.Kes/Per/IX/1990 tentang Syarat-syarat dan Pengawasan Kualitas Air Minum. 
Pengolahan air baku yang berupa air gambut merupakan upaya untuk mendapatkan air yang bersih dan sehat sesuai dengan standar baku mutu. Proses pengolahan air minum merupakan proses perubahan sifat fisika, kimia dan biologi air agar memenuhi syarat untuk digunakan sebagai air minum. Pengolahan air baku merupakan upaya untuk mendapatkan air yang bersih dan sehat sesuai dengan standar baku mutu. Proses pengolahan air minum merupakan proses perubahan sifat fisika, kimia dan biologi air agar memenuhi syarat untuk digunakan sebagai air minum (BPPT, 2002). Efisiensi instalasi pengolahan yang digunakan dipengaruhi oleh beberapa faktor antara lain oleh perlakuan air baku pra pengolahan, pengolahan dan pos pengolahan (Djasio Suropie, 1984).

Termasuk pengolahan air gambut menjadi air bersih dapat dilakukan dengan proses yang sederhana dengan kombinasi proses netralisasi, aerasi, flokulasi-koagulasi, pengendapan dan penyaringan (Widayat et al. 2001).

Menurut Suhana (2004), pengolahan air gambut untuk masyarakat desa kawasan tanah gambut dapat dilakukan dengan memanfaatkan kearifan lokal dengan program pemberdayaan berbasis masyarakat.

Pada penelitian model pengelolaan air gambut menjadi air bersih secara kontinyu dengan rancangan alat dan bahan lokal dapat dilakukan dengan menambahkan beberapa bahan kimia. Penelitian ini mencoba menganalisis hasil olahan air gambut menjadi air bersih secara kontinyu dengan menggunakan material pasir, kerikil, ijuk dan bahan kimia seperti kapur dan tawas untuk dibandingkan dengan.

\section{TINJAUAN PUSTAKA}

Penelitian air gambut diolah menjadi air bersih telah banyak dilakukan berkaitan dengan karakteristik air gambut dan cara pengolahannya. Air gambut mempunyai $\mathrm{pH}$ antara 3-5 menjadikan air gambut bersifat asam. Kandungan tersuspensi air gambut rendah, kandungan zat organik yang tinggi dan intensitas zat warna yang tinggi (Suherman, 2013). Menurut Kiswanto ( 2017), air gambut dapat diolah menjadi air bersih/minum menggunakan model alat penyaring air gambut dengan media tawas, pasir, dan arang tempurung didapatkan hasil yang telah memenuhi standar baku air minum untuk beberapa parameter ( Fe, TDS, pH, Zn, F, NO3 dan NO2 ) sesuai dengan Permenkes RI NO. 907 Tahun 2002.

\subsection{Karakteristik Air Gambut}

Air gambut merupakan air permukaan yang terdapat di daerah gambut yang tersebar di dataran rendah di wilayah Kalimantan dan Sumatera. Karakteristik air gambut mempunyai intensitas warna yang tinggi (berwarna merah kecoklatan), derajat keasaman tinggi (nilai $\mathrm{pH}$ rendah), kandungan zat organik tingggi, sementara konsentrasi partikel tersuspensi dan ion rendah (Samosir, 2009).

Konsentrasi zat organik di dalam air gambut terlihat dari warnanya, semakin pekat warnanya semakin tinggi kandungan zat organiknya.Air gambut adalah air permukaan yang banyak terdapat di daerah rawa maupun dataran rendah, yang mempunyai ciri-ciri sebagai berikut (Kusnaedi, 2006):

a) Nila $\mathrm{pH}$ yang rendah.

b) Intensitas warna yang tinggi (berwarna merah kecoklatan).

c) Kandungan zat organik yang tinggi.

d) Kandungan kation yang rendah.

e) Kekeruhan dan kandungan partikel tersuspensi yang rendah. 
Air gambut mengandung senyawa organik terlarut yang menyebabkan air menjadi berwarna dan bersifat asam. Senyawa organik tersebut adalah asam humus yang terdiri dari asam humat, asam sulvat, dan humin. Asam humus adalah senyawa organik dengan berat molekul tinggi dan berwarna coklat sampai kehitaman.

\subsection{Parameter Kualitas Air Gambut}

2.2.1. Nilai $\mathrm{pH}$

Parameter $\mathrm{pH}$ dari air minum yang masih diizinkan oleh Permenkes RI No.416/Menkes/PER/IX/1990 tentang Persyaratan Kualitas Air Bersih adalah dalam rentang 6,5-9,0. Nilai $\mathrm{pH}$ digunakan untuk menyatakan tingkat keasaaman atau basa yang dimiliki oleh suatu zat, larutan atau benda. Nilai pH normal memiliki nilai 7 sementara bila nilai $\mathrm{pH}>7$ menunjukkan zat tersebut memiliki sifat basa sedangkan nilai $\mathrm{pH}<7$ menunjukkan sifat asam. Nilai $\mathrm{pH} 0$ menunjukkan derajat keasaman yang tinggi, dan $\mathrm{pH} 14$ menunjukkan derajat kebasaan tertinggi. Umumnya indikator sederhana yang digunakan adalah kertas lakmus yang berubah menjadi merah bila keasamannya tinggi dan biru bila keasamannya rendah.

2.2.2. Warna

Warna adalah salah satu parameter fisik wajib yang ditetapkan oleh Permenkes RI No.416/Menkes/PER/IX/1990. Pada Kepmenkes RI No. 416 Tahun 1990 menyatakan bahwa batas maksimal warna air bersih maksimal 50 skala TCU. Dalam analisis warna, alat yang digunakan adalah spektrofotometer. Warna pada air gambut disebabkan karena adanya partikel koloid organik yang merupakan hasil dekomposisi dari tanaman.

\subsubsection{Kekeruhan}

Kekeruhan air dapat ditimbulkan oleh adanya bahan-bahan organik dan anorganik yang terkandung di dalam air seperti lumpur dan bahan-bahan yang berasal dari buangan. Bahan-bahan yang menyebabkan kekeruhan ini meliputi tanah liat, lumpur, bahan-bahan organik yang tersebar secara baik dan partikelpartikel kecil tersuspensi lainnya. Kekeruhan sering diukur dengan menggunakan metode Nephelometric. Satuan kekeruhan yang diukur dengan menggunakan Nephelometric adalah NTU (Nephelometric Turbidity Unit). Permenkes RI No.416/Menkes/ PER/IX/1990 menetapkan standar kualitas air bersih untuk kekeruhan yaitu 25 dalam satuan NTU.

2.2.4 Kandungan Organik $\mathrm{KMnO} 4$

Zat organik adalah zat yang banyak mengandung unsur karbon. Contohnya antara lain benzen, chloroform, detergen, methoxychlor, dan pentachlorophenol. Dengan adanya kandungan zat organik di dalam air berarti air tersebut sudah tercemar, terkontaminasi rembesan dari limbah dan tidak aman sebagai sumber air bersih dan minum. Parameter ini memiliki batasan maksimal 10 mg/liter berdasarkan Permenkes RI No.416/Menkes/ PER/IX/1990 tentang persyaratan kualitas air.

\subsection{Pengolahan Air Gambut Secara Kontinyu}

Pengolahan air secara kontinyu memiliki prinsip kerja yang sama dengan biosand filter, yang membedakannya hanya jenis media penyaringan yang digunakan. Biosand filter dual media menggunakan media filtrasi berupa pasir kuarsa, kerikil, 
arang tempurung dan ijuk sedangkan biosand filter biasa hanya menggunakan satu media filtrasi berupa pasir.

Biosand filter dual media merupakan adaptasi dari saringan slow sand tradisional yang telah digunakan untuk proses penyaringan atau penjernihan air, dimana air yang akan diolah dilewatkan pada suatu media porous yang dipengaruhi oleh diameter butir pasir dan batu apung dengan kecepatan tertentu. Wadah filter dapat dibuat dari beton atau plastik dan diisi dengan lapisan butiran pasir kuarsa, batu apung, ijuk, tempurung kelapa dan kerikil yang telah ditentukan effective size dan disiapkan secara khusus.

\section{METODE PENELITIAN}

Pengolahan air gambut menjadi air bersih secara kontinyu di Desa Peunaga Cut Ujong Meureubo Aceh Barat. Penelitian ini bersifat eksperimen sekaligus untuk aplikasi penerapannya dilapangan. Pengolahannya sangat sederhana karena material mudah didapat dari alam langsung.

\subsection{Materi Penelitian}

Bahan yang digunakan adalah air gambut, kaporit, kapur tohor, tawas, kerikil, arang, pasir dan ijuk. Alat yang digunakan tanki tower air berbentuk silinder tinggi media filtrasi $45 \mathrm{~cm}$ sebanyak 3 buah dengan kapasitas 500 liter, serta dilengkapi dengan sebuah kran disebelah bawah. Peralatan yang digunakan untuk uji hasil sampel adalah Spektrofotometer sinar tampak, spektrofotometer serapan atom (AAS), flame fotometer, hellige turbidimeter, dan seperangkat alat analisis volumetri.

3.2. Proses Pengolahan Air Gambut (Widayat, 2001)

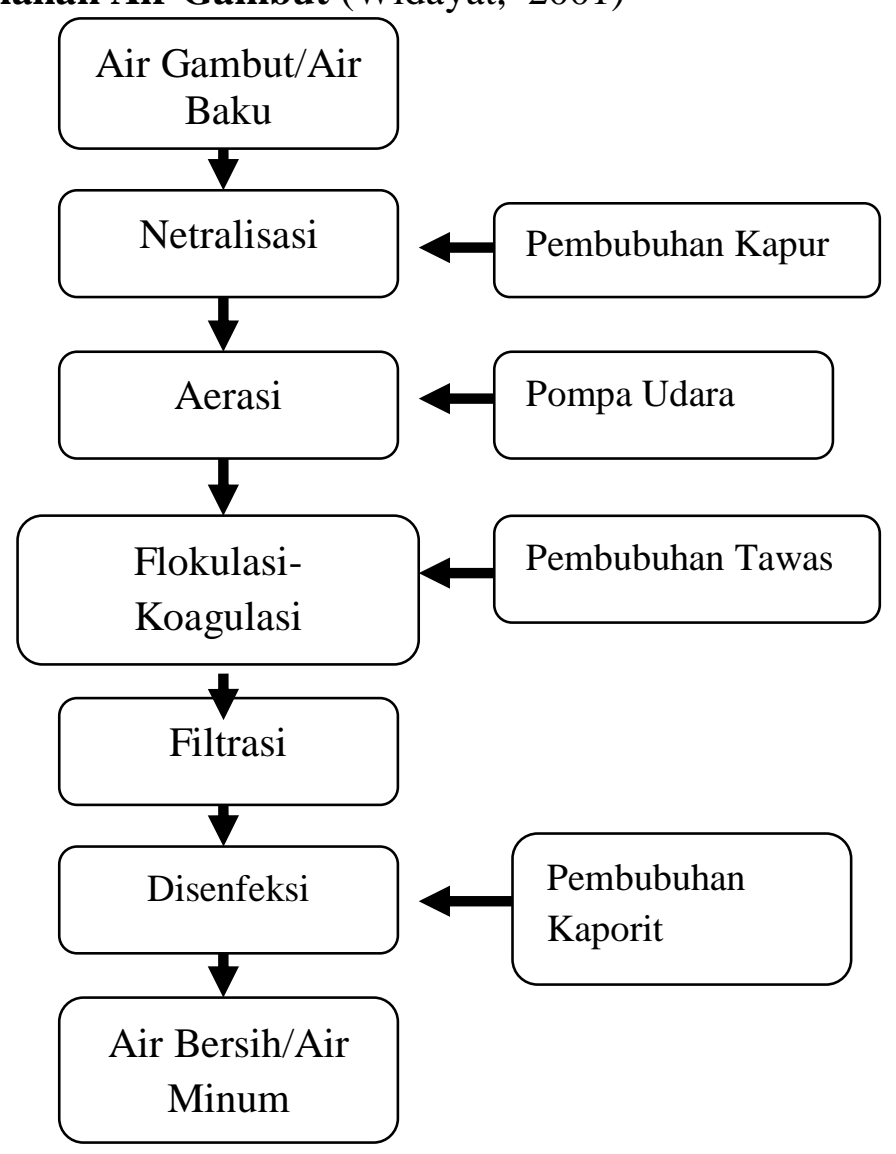

Gambar 1 Diagram Proses Pengolahan Air Gambut 


\subsubsection{Netralisasi}

Netralisasi adalah mengatur keasaman air baku yang bersifat asam dengan $\mathrm{pH}<7$ dinaikkan menjadi netral ( $\mathrm{pH} 7$ - 8), dengan cara pembubuhan alkali. Cara yang paling mudah dan murah yaitu dengan membubuhkan larutan air kapur /gamping. Tujuan netralisasi ini adalah untuk membantu efektiitas proses selanjutnya yaitu oksidasi dan koagulasi-flokulasi selain itu hal yang tidak kalah penting adalah air olahan yang dihasilkan netral sesuai dengan kualitas air minum (pH 6-8,5)

\subsubsection{Aerasi}

Proses aerasi yaitu mengontakkan air baku dengan udara kususnya oksigen $\left(\mathrm{O}_{2}\right)$, dengan tujuan zat besi $(\mathrm{Fe})$ dan mangan $(\mathrm{Mn})$ yang terdapat dalam air baku teroksidasi dan selanjutnya membentuk senyawa besi dan mangan yang dapat diendapkan. Disamping itu proses aerasi juga berfungsi untuk menghilangkan gas-gas beracun yang tak diinginkan misalnya gas $\mathrm{H}_{2} \mathrm{~S}$, methan, karbon dioksida dan gas-gas racun lainnya. Oksidasi mangan dengan oksigen dari udara tidak seefektif untuk besi, tetapi jika kadar mangannya tidak terlalu tinggi maka sebagian mangan dapat juga teroksidasi dan terendapkan.

Reaksi oksidasi besi dan mangan oleh udara adalah sebagai berikut:

$$
4 \mathrm{Fe}^{2+}+\mathrm{O}_{2}+10 \mathrm{H}_{2} \mathrm{O} \quad 4 \mathrm{Fe}(\mathrm{OH})_{3}+8 \mathrm{H}^{+}
$$

tak larut

$$
2 \mathrm{Mn}^{2+}+\mathrm{O}_{2}+2 \mathrm{H}_{2} \mathrm{O} \quad 2 \mathrm{MnO}_{2}+4 \mathrm{H}^{+}
$$

tak larut

\subsubsection{Koagulasi-Flokulasi}

Koagulasi dilakukan dengan pembubuhan bahan koagulan ke dalam air baku, dimana kotoran yang berupa koloid maupun suspensi yang ada di dalamnya menggumpal sehingga mudah diendapkan. Kotoran yang berupa koloid maupun suspensi halus, antara lain zat warna organik, lumpur halus, bakteri dan algae serta lainnya tidak dapat mengendap secara alamiah karena partikelnya sangat halus.

Selain itu pada umumnya partikel-partikel kotoran tersebut mempunyai kelebihan muatan elektron negatip sehingga terjadi tolak-menolak antar partikel yang menyebabkan sulit mengendap.Oleh karena itu koagulasi dapat berjalan dengan baik apabila penyebabnya dapat dihilangkan yaitu dengan menetralisasi kelebihan muatan negatif partikel kotoran. Netralisasi tersebut dapat dilakukan dengan cara pembubuhan zat koagulan yaitu bahan atau alat yang mempunyai kemampuan menetralisir muatan negatif partikel kotoran dan kemampuan mengikat partikel-partikel tersebut.

\subsubsection{Pengendapan}

Tujuan pengendapan atau sedimentasi adalah mengendapkan gumpalan yang terjadi akibat proses koagulasi-flokulasi secara gravitasi, selain itu proses pengendapan ini mengurangi beban kerja filter. Pengendapan dilakukan dengan cara membiarkannya selama kurang lebih satu jam, tergantung pada besar kecilnya flok-flok yang terbentuk. 


\subsubsection{Penyaringan}

Gumpalan partikel atau flok yang terjadi tidak semuanya dapat diendapkan. Flok-flok yang relatif kecil dan halus masih melayang-layang dalam air.Oleh karena itu, untuk mendapatkan air yang betul-betul jernih harus dilakukan penyaringan atau filtrasi.Filtrasi dilakukan dengan media penyaring yang terdiri dari kerikil, arang/karbon aktif, ijuk dan pasir.

\subsection{Spesifikasi Peralatan}

\subsubsection{Unit Kontrol}

Unit kontrol berfungsi untuk menyediakan dan mengatur laju alir air baku, larutan kapur dan larutan tawas yang dikontrol dengan pengaturan pembukaan valve. Unit kontrol terdiri dari pompa air baku dengan kapasitas 30 liter/menit, bak penampung air baku, bak penampung larutan kapur dan bak penampung larutan tawas. Bak penampung masing-masing dilengkapi dengan valve pembuangan endapan dan valve untuk mengatur laju alir.

\subsubsection{Unit Netralisasi}

Dalam unit ini larutan kapur dicampur sampai homogen/rata dengan kecepatan pengadukan tertentu dengan air baku untuk menetralkan $\mathrm{pH}$ air gambut.

\subsubsection{Unit Aerasi}

Unit ini dilengkapi dengan aerator atau dengan pompa manual, untuk memasukkan udara kedalam air baku dengan tujuan zat besi atau mangan yang terlarut dalam air baku bereaksi dengan oksigen yang ada dalam udara membentuk oksida besi atau oksida mangan yang dapat diendapkan. Aerator/pompa angin manual dihubungkan dengan difucer untuk menyebarkan udara yang dihembuskan oleh aerator ke dalam air baku.

3.3.4. Unit Koagulasi-Flokulasi

Dalam unit ini larutan bahan koagulan dicampur sampai homogen dengan kecepatan pengadukan tertentu untuk menghindari flok-flok yang pecah, sehingga kotoran yang berupa koloid maupun suspensi yang ada di dalamnya menggumpal dan mudah diendapkan pada bak pengendapan.

\subsubsection{Unit Pengendapan}

Unit pengendapan atau disebut dengan unit sedimentasi yang berfungsi untuk mengendapkan gumpalan yang terjadi akibat proses koagulasi-flokulasi secara gravitasi dengan waktu tinggal \pm 1 jam. Unit ini dilengkapi dengan valve/back wash pembuangan endapan dan pengurasan

\subsubsection{Unit Penyaring}

Unit penyaring terdiri dari tanki tower air berbentuk silinder tinggi media filtrasi $45 \mathrm{~cm}$ sebanyak 3 buah dengan kapasitas 500 liter, serta dilengkapi dengan sebuah keran disebelah bawah. Untuk media penyaring digunakan pasir, kerikil, arang dan ijuk. Susunan media penyaring media penyaring dari yang paling dasar keatas adalah sebagai berikut :

a) Lapisan 1 : Kerikil atau koral dengan diameter 1-3 cm, tebal lapisan 5$7 \mathrm{~cm}$

b) Lapisan 2: Ijuk dengan ketebalan 3-5 cm

c) Lapisan 3: Arang tempurung kelapa atau arang kayu yang lain dengan ketebalan $10 \mathrm{~cm}$. 


\subsection{Analisis Data}

d) Lapisan 4: Kerikil Kecil diameter $5 \mathrm{~mm}$ ketebalan $5 \mathrm{~cm}$.

e) Lapisan 5: Pasir dengan diameter 0,5 $\mathrm{mm}$ ketebalan $15 \mathrm{~cm}$.

f) Lapisan 6: Kerikil diameter $3 \mathrm{~cm}$ tebal $5 \mathrm{~cm}$.

Data yang diperoleh dianalisis untuk mengetahui apakah ada penurunan yang signifikan pada parameter warna, bau, rasa, kekeruhan, $\mathrm{pH}$, kesadahan, zat organik, flurode, Nitrat, Nitrit, kandungan logam (Fe, Zn) sebelum dan setelah pengolahan dengan pengolahan air gambut secara kontinyu variasi media filtrasi. Data kualitas air baku dan produk olahan dibandingkan dengan standar air bersih sesuai dengan Permenkes No.416/MENKES/PER/IX/1990.

\section{HASIL DAN PEMBAHASAN}

\subsection{Hasil Olahan Air Gambut}

Air gambut yang berada dalam kolam penampungan yang merupakan air baku diendapkan terlebih dahulu untuk selanjutnya dilakukan ;

Netralisasi untuk mengatur keasaman air gambut yang merupakan air baku yang diolah menjadi air bersih dinetralkan hingga $\mathrm{pH}$ 7-8. Setelah dilakukan netralisasi baru dilakukan proses aerasi dengan mengontakkan air gambut dengan udara khususnya oksigen $\left(\mathrm{O}_{2}\right)$ dengan tujuan zat besi $(\mathrm{Fe})$ yang terdapat pada air gambut teroksidasi dan selanjutnya membentuk senyawa besi yang dapat diendapkan.

Pengendapan ini selanjutnya dilakukan koagulasi dengan pembubuhan bahan koagulan ke dalam air gambut, supaya koloid maupun suspensi yang ada di dalamnya menggumpal sehingga mudah diendapkan. Pengendapan ini adalah proses sedimentasi untuk mengendapkan semua koloid dengan cara pembubuhan bahan kimia seperti kapur dan tawas yang bertujuan untuk mempercepat sedimentasi dan membutuh bakteri yang ada dalam air. Selanjutnya dilakukan filtrasi dengan penyaringan melalui penyaring dari kerikil, pasir, arang, dan ijuk.

Dari proses penyaringan inilah dibubuhi disenfeksi untuk membunuh bakteri/virus dalam air. Air baku yang berupa air gambut sudah menjadi air bersih selanjutnya dilakukan uji analisis untuk mengetahui parameter air olahan air yang hasilnya dibandingkan standar air bersih sesuai dengan Permenkes No.416/MENKES/PER/IX/1990.

Tabel 1 Perbandingan air gambut, air hasil olahan dan Permenkes No.416/Menkes/Per/ix/1990

\begin{tabular}{|c|c|c|c|c|c|}
\hline No & Parameter & Unit & $\begin{array}{c}\text { Air } \\
\text { Gambut }\end{array}$ & $\begin{array}{c}\text { Air } \\
\text { Olahan }\end{array}$ & $\begin{array}{c}\text { Permenkes } \\
\text { No.416/MENKES/PER/IX/1990 }\end{array}$ \\
\hline 1 & Warna & Skala TCU & 120 & 8 & 15 \\
\hline 2 & $\mathrm{Bau}$ & & $\mathrm{Bau}$ & - & - \\
\hline 3 & Rasa & & Berasa & - & - \\
\hline 4 & $\mathrm{pH}$ & & 4.5 & 7.6 & $6,5-8,0$ \\
\hline 5 & Turbidity & NTU & 37 & 3 & 5 \\
\hline 6 & Zat Organik $\left(\mathrm{KMnO}_{4}\right)$ & $\mathrm{Mg} / \mathrm{l}$ & 15 & 4 & 10 \\
\hline 7 & Kesadahan $\left(\mathrm{CaCO}_{3}\right)$ & $\mathrm{Mg} / \mathrm{l}$ & 88 & 53 & 500 \\
\hline 8 & $\operatorname{Besi}(\mathrm{Fe})$ & $\mathrm{Mg} / \mathrm{l}$ & 1.5 & 0.08 & 0,3 \\
\hline 9 & Seng (Zn) & $\mathrm{Mg} / \mathrm{l}$ & 1.46 & 0.13 & 5,3 \\
\hline 10 & Flurode & $\mathrm{Mg} / \mathrm{l}$ & 1.5 & 0.34 & 1,5 \\
\hline 11 & $\mathrm{NO}_{3}$ & $\mathrm{Mg} / \mathrm{l}$ & 2.1 & 0.419 & 10 \\
\hline 12 & $\mathrm{NO}_{2}$ & $\mathrm{Mg} / \mathrm{l}$ & 3.2 & 0.022 & 1,05 \\
\hline
\end{tabular}


Hasil pengujian ini menunjukkan bahwa air gambut pada kolam penampungan untuk dijadikan air baku menjadi air bersih sudah layak.

\subsection{Hasil Penyisihan dari Filtrasi Secara Kontinyu}

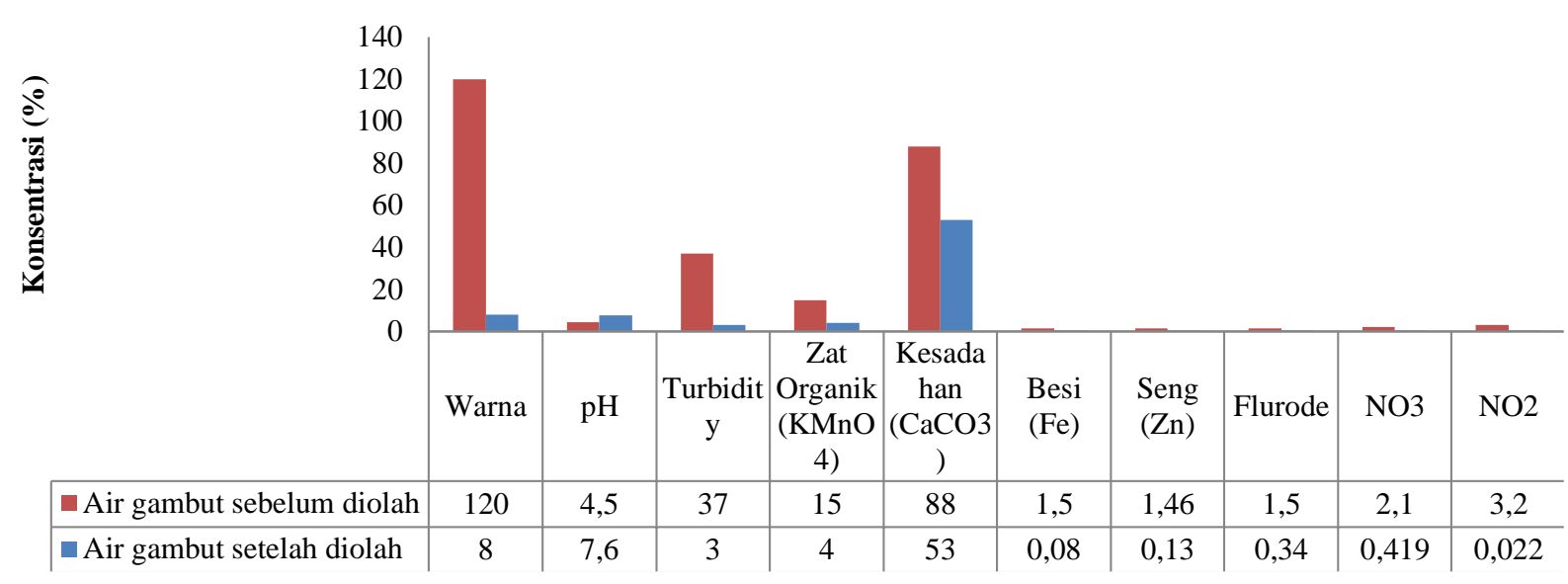

Gambar 1 Perbandingan air gambut sebelum diolah dan sesudah diolah

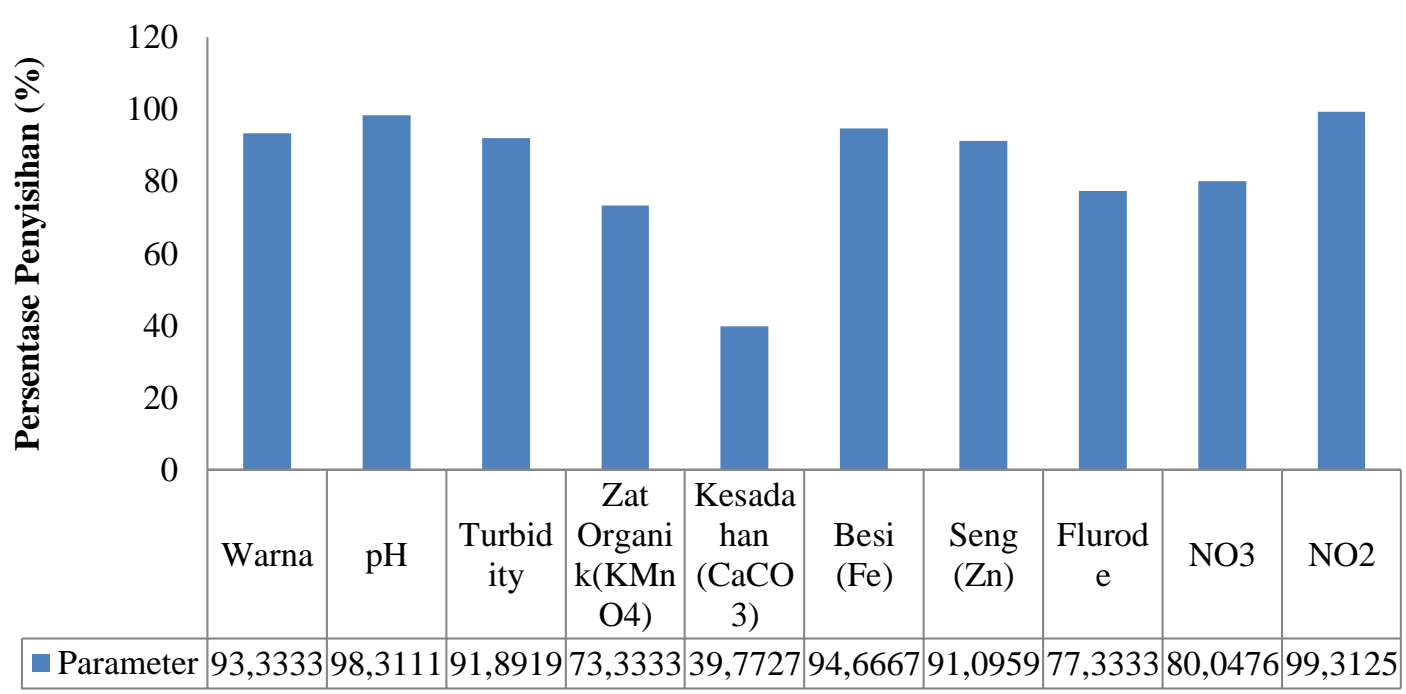

Gambar 2 Persentase penyisihan parameter air gambut

Dari hasil gambar 2 dan 3 terlihat bahwa hasil penyisihan air gambut menjadi air bersih sebelum diolah dan setelah proses pengolahan mengalami perubahan secara signifikan. Perubahan ini dapat dilihat pada gambar 3 yang menunjukkan penurunan untuk parameter warna mencapai 93,3\%, pH sebesar 98,3\%, Turbidity/kekeruhan mencapai 91,9\%, Zat Organik (KMNO4) sebesar 73,3\%, Kesadahan sebesar 39,7\%, Zat besi (Fe) sebesar 94,6\%, Seng (Zn) sebesar 91,09\%, Flurode sebesar 77,33\%, Nitrat $\left(\mathrm{NO}_{3}\right)$ sebesar $80,04 \%$, dan Nitrit $\left(\mathrm{NO}_{2}\right)$ sebesar $99,31 \%$.

Pengolahan air gambut secara kontinyu dengan menggunkan bahan-bahan alam seperti pasir, ijuk, arang dan tambahan bahan kimia seperti kapor, tawas dan kaporit mampu untuk mampu menyisihkan bahan-bahan organik dan logam berat dalam air gambut. Hal ini sesuai dengan penelitian Kiswanto (2017), Model alat penyaringan air 
gambut dengan media tawas, pasir dan arang tempurung didapatkan hasil yang telah memenuhi standar baku air minum untuk beberapa parameter ( Fe, TDS, pH, Zn, F, NO3 dan NO2 ) sesuai dengan Permenkes RI NO. 907 Tahun 2002.

Pengolahan air gambut menjadi air bersih dapat juga dilakukan dengan beberapa material dari alam salah satunya adalah lempung/kaolin. Dalam penelitian Dadan Suherman (2013) bahwa tanah lempung mampu mengurangi zat warna pada air gambut dan mampu mengikat logam berat.

\section{SIMPULAN DAN SARAN}

\subsection{Simpulan}

Hasil dari penelitian ini dapat disimpulkan bahwa untuk mengolah air gambut menjadi air bersih dapat dilakukan dengan proses yang sederhana dengan kombinasi proses netralisasi, aerasi, flokulasi-koagulasi, pengendapan dan penyaringan. Pengolahan air gambut diwilayah lahan gambut menjadi air bersih dapat dilakukan dengan proses penyaringan yang sederhana hanya menambahai beberapa bahan kimia yang tidak berbahaya. Pengolahan air gambut sangat bermanfaat membantu masyarakat pedesaanyang mengalami kelangkaar air bersih untuk memenuhi kebutuhannya seperti kebutuhan mandi dan cuci. Sedangkan untuk kebutuhan air minum perlu dilakukan pemasakkan terlebih dahulu.

Dari penelitian yang bersifat aplikatif dilapangan dapat ditemukan cara-cara sederhana untuk menghilangkan warna dan zat organik dalam air gambut yaitu: setiap 1000 (seribu) $\mathrm{ml}$ air gambut diperlukan penambahan : 0,10 gram kaporit; 0,05 gram kapur tohor; dan 0,40 gram tawas. Setiap penambahan zat, dilakukan pengadukan secara manual atau menggunakan stirer kurang lebih 30 detik. Hanya dalam waktu 5 menit, terbentuk larutan yang bening dan endapan/gumpalan berwarna coklat.

Pada uji coba penelitian ini telah dilakukan penghilangan warna mencapai 93,3\%, pH sebesar 98,3\%, Turbidity/kekeruhan mencapai 91,9\%, Zat Organik (KMNO4) sebesar 73,3\%, Kesadahan sebesar 39,7\%, Zat besi (Fe) sebesar 94,6\%, Seng (Zn) sebesar 91,09\%, Flurode sebesar 77,33\%, Nitrat $\left(\mathrm{NO}_{3}\right)$ sebesar 80,04\%, dan Nitrit $\left(\mathrm{NO}_{2}\right)$ sebesar 99,31\%. Sementara hasil untuk air olahan air gambut sudah tidak berbau dan berasa lagi.

Hasil dari uji coba ini masih dibawah baku mutu Permenkes RI No.416/Menkes/ PER/IX/1990 tentang persyaratan kualitas air.

\subsection{Saran}

Pengolahan air baku dari gambut dapat dirancang ulang yang lebih sederhana lagi untuk memudahkan masyarakat pedesaan. Karena pada perancangan ini masih membutuhkan proses yang agak rumit. Untuk mencukupi masyarakat luas khususnya di daerah gambut perlu dibangun PAM berbasis masyarakat yang melibatkan pemerintah daerah.

Untuk mengolah air gambut kapasitas 100 liter air gambut yang sudah diendapkan dibutuhkan 20 gram kapur dan 20 gram tawas. Sedangkan untuk proses filter dapat digunkan bahan-bahan alami seperti kerikil, pasir, arang dan ijuk. 


\section{DAFTAR PUSTAKA}

BPPT, 2002, Teknologi Pengolahan Limbah Cair Industri, BPPT, Jakarta

Djasio Suropie. 1984. Standar Kualitas Air. Jakarta

Kiswanto., Wintah., Hafni, N., dan Duana, M. 2017. Model Pengolahan Air Gambut Menjadi Air Minum Berbasis Masyarakat. Journal Of Aceh Aquatic Science. 1 (1): 220-230.

Kusnaedi. 2006. Mengolah Air Gambut dan Air Kotor untuk Air Minum. Penebar Swadaya. Jakarta

Peraturan Menteri Kesehatan RI No. 416/Men.Kes/Per/IX/1990 tentang Syarat-syarat dan Pengawasan Kualitas Air Minum.

Samosir, A. 2009. Pengaruh Tawas Dan Diatomea (Diatomaceous Earth) Dalam Proses Pengolahan Air Gambut Dengan Metode Elektrokoagulasi. Skripsi. Departemen Kimia. Fakultas Matematika Dan Ilmu Pengetahuan Alam. Universitas Sumatera Utara.

Suhana, A. 2004. Membuat Perangkat Air Siap Minum. Puspa Swara. Jakarta.

Suherman, D dan Nyoman, S. 2013. Menghilangkan Zat Warna dan Zat Organik Air Gambut dengan Metode Koagulasi-Flokulasi Suasana Basa. Ris.Geo. 23 (2): 125-137.

Widayat, W.,Said, N.I. 2001. Pengolahan air gambut secara Kontinyu. Jurnal Teknologi Lingkungan . Vol. 2. No.3 : 214-222

Zouboulis, A.I., Chai, X.L., dan Katsoyiannis, I.A. 2004.The Application of Bioflocculant for The Removal of Humic Acids rom Stabilized Landfill Leachates. Environmental Management Journal. 70: 35-41. 